\title{
PRIORITAS ALTERNATIF PENINGKATAN KINERJA COMMUTER- LINE DI MASA PANDEMI COVID-19
}

\author{
imma widyawati agustin ${ }^{1}$, septiana hariyani ${ }^{2}$, sherly oktafia damayanti ${ }^{3}$ \\ Jurusan Perencanaan Wilayah dan Kota, Universitas Brawijaya ${ }^{123}$ \\ e-mail: ${ }^{* 1}$ immasaitama@ub.ac.id, ${ }^{2}$ septianahariyani@ub.ac.id, ${ }^{3}$ sherlyoktafiadamayanti@gmail.com
}

\begin{abstract}
Surabaya City is the National Activity Center in East Java which has a heterogeneous function and serves as the center of orientation for the activities of residents living in the surrounding area. Every day many commuters are active in Surabaya City. The highest number of commuters came from Sidoarjo Regency with 169.560 people or $40 \%$ of the total 423.109 people. However, of the total commuters, only 1.246 people, or $0,7 \%$ of the 169.560 commuters rely on the commuter line, while the number of private vehicle users is 159.190 people. This causes congestion with the movement pattern of private vehicles in the Sidoarjo region to Surabaya with a volume of $3.491 \mathrm{pcu} / \mathrm{hour}$ with an LOS of 0,90 to 1,58 . One of the government's efforts to reduce the use of private vehicles is to provide mass transportation in the form of commuter lines. This study aims to evaluate the operational performance and service of the commuter line Surabaya-Pasuruan route to determine which aspects need to be prioritized to serve optimally. The data obtained through observation and questionnaires were reviewed using operational performance analysis (load factor, headway, travel time, waiting time), IPA, and QFD. The results of the operational performance analysis showed various problems, namely the load factor exceeding the $60 \%$ standard carrying capacity due to Covid-19 adaptation and waiting time exceeding the maximum standard of 20 minutes. The priority of technical response directives is obtained in improving operational and service performance, namely the periodic maintenance and inspection of railway facilities.
\end{abstract}

Keywords: commuter line, quality function deployment, importance performance analysis

\begin{abstract}
ABSTRAK
Kota Surabaya sebagai Pusat Kegiatan Nasional di Jawa Timur yang memiliki fungsi heterogen dan menjadikan sebagai pusat orientasi kegiatan penduduk yang tinggal di wilayah sekitarnya. Setiap harinya terdapat banyak penglaju yang beraktivitas di Kota Surabaya. Berdasarkan statistik komuter Gerbangkertosusila 2017, penglaju terbanyak berasal dari Kabupaten Sidoarjo sebanyak 169.560 jiwa atau $40 \%$ dari total 423.109 jiwa. Namun dari total penglaju hanya 1.246 jiwa atau 0,7\% dari 169.560 penglaju yang mengandalkan commuter line, sedangkan jumlah pengguna kendaraan pribadi sebanyak 159.190 jiwa. Hal tersebut menyebabkan kemacetan dengan pola pergerakan kendaraan pribadi di wilayah Sidoarjo menuju Surabaya memiliki volume sebesar $3.491 \mathrm{smp} / \mathrm{jam}$ dengan LOS sebesar 0,90 hingga 1,58. Salah satu upaya pemerintah untuk mengurangi penggunaan kendaraan pribadi adalah menyediakan transportasi massal berupa commuter line. Penelitian ini bertujuan melakukan evaluasi kinerja operasional dan pelayanan commuter line rute SurabayaPasuruan untuk mengetahui aspek-aspek yang perlu diprioritaskan penanganannya agar melayani secara optimal. Data yang diperoleh melalui observasi dan kuesioner ditinjau menggunakan analisis kinerja operasional (load factor, headway, travel time, waktu tunggu), metode IPA, dan metode QFD. Hasil analisis kinerja operasional menunjukkan berbagai permasalahan yaitu load factor melebihi standar kapasitas angkut $60 \%$ akibat adaptasi covid-19 dan waktu tunggu melebihi standar maksimal 20 menit. Pada metode IPA didapatkan 7 atribut pelayanan dalam kuadran I yaitu pintu kereta, keteraturan jadwal, informasi gangguan, fasilitas penumpang difabel, tempat kursi roda, fasilitas jaga
\end{abstract}


jarak, serta pembersihan fasilitas. Prioritas alternatif peningkatan kinerja operasional dan pelayanan yaitu perawatan dan pemeriksaan sarana perkeretaapian secara berkala.

Kata kunci: commuter line, quality function deployment, importance performance analysis

\section{PENDAHULUAN}

Transportasi adalah salah satu fasilitas bagi suatu daerah untuk maju dan berkembang dan bermanfaat meningkatkan hubungan atau aksesibilitas suatu daerah. Hal tersebut dikarenakan aksesibilitas sering dikaitkan dengan daerah (Sarafina, Usman, \& Adamy, 2019). Kota merupakan kawasan dengan fasilitas yang lengkap dan memiliki banyak pusat kegiatan menyebabkan banyak orang yang berpindah ke kota sehingga dekat dengan pusat-pusat untuk memenuhi kebutuhannya. Tingkat kepadatan penduduk kota yang tinggi seperti pada kawasan metropolitan akan memiliki pengaruh signifikan terhadap kemampuan transportasi melayani kebutuhan masyarakat (Fadjar, Wiwandari, \& Jawoto, 2018). Salah satu contoh perubahan paling luar biasa dalam kebijakan transportasi di AS selama beberapa dekade terakhir adalah pergeseran dari strategi pasokan transportasi ke manajemen permintaan transportasi (TDM) dalam menanggapi peningkatan kemacetan lalu lintas dan masalah lingkungan yang terkait dengan mobil (Meyer, 1999). Tidak seperti strategi konvensional yang ditujukan untuk meningkatkan kapasitas jalan untuk mengelola peningkatan lalu lintas, kebijakan TDM mengatasi sisi permintaan dengan mengurangi perjalanan kendaraan single occupancy. Program TDM berbasis pengusaha adalah bagian dari upaya untuk mengendalikan permintaan perjalanan secara efektif, karena perjalanan komuter cenderung terkonsentrasi di daerah padat, seperti pusat kota, terutama pada jam sibuk (Modarres, 1993).

Diantara pemberi kerja yang diamanatkan oleh pemerintah negara bagian atau lokal untuk mengurangi porsi karyawan mereka yang mengemudi sendiri untuk bekerja, banyak yang memperpanjang program tunjangan komuter yang sebelumnya hanya mensubsidi biaya yang terkait dengan mobil. Oleh karena itu, terdapat peningkatan diversifikasi manfaat komuter untuk memasukkan subsidi untuk moda transportasi alternatif, meskipun parkir yang disediakan oleh pemberi kerja tetap menjadi jenis manfaat yang paling umum di Amerika Serikat (Society for Human Resource Management, 2017). Salah satu masalah paling serius di kota-kota besar adalah kemacetan lalu lintas, yang mempengaruhi perjalanan harian baik di atas maupun di bawah tanah. Permintaan besar-besaran selama jam sibuk menyebabkan gerbong kereta bawah tanah yang padat, operasi yang tidak stabil dan pengalaman penumpang yang melelahkan (Tirachini et al., 2013). Di wilayah metropolitan, seperti Bogota, Sao Paulo, Beijing, Tokyo, dan Singapura, sebanyak sembilan atau sepuluh penumpang dapat memadati ruang berdiri seluas satu meter persegi pada jamsibuk pagi hari. Karena batas atas pasokan layanan transportasi kereta bawah tanah, dan sulitnya meningkatkan batas, banyak otoritas transit telah mengadopsi kebijakan manajemen permintaan untuk mendorong komuter untuk terlibat dalam penghindaranpuncak, yaitu bepergian selama jam tidak sibuk untuk mengurangi permintaan perjalanan. selama jam sibuk. Contoh prakarsa penghindaran puncak termasuk kampanye "BepergianLebih Awal, Bebas Bepergian" dan tantangan "Bebaskan Tempura dan Soba" di Tokyo, selain sistem penetapan harga diferensial jam sibuk dan tidak sibuk yang ada di banyak kota (Yang dan Lim, 2018). Seperti kota-kota besar lainnya di dunia, Beijing juga memiliki sistem kereta bawah tanah yang sangat padat. Tingkat hunian rata-rata sistem kereta 
bawah tanah Beijing selama jam sibuk mencapai 135\% (Zhang et al., 2014). Untuk mengurangi kemacetan, Beijing telah menerapkan strategi penetapan harga variabel yang mencakup pengurangan 30\% tarif untuk 16 stasiun di Jalur Batong dan Changping untuk penumpang yang berangkat sebelum pukul 7:00 pada tahun 2015 dan diskon meningkat menjadi pengurangan 50\% pada tahun 2016. Terlepas dari diskon tarif ini, tidak ada penurunan nyata dalam permintaan puncak yang diamati (Zou et al., 2018).Kota Surabaya sebagai ibukota Jawa Timur merupakan wilayah metropolitan terbesar kedua di Indonesia dengan jumlah penduduk pada tahun 2018 sebesar 3.094.732 jiwa (Kota Surabaya Dalam Angka, 2019). Berdasarkan PP No 5 Tahun 2012 tentang RTRW Provinsi Jawa Timur 20112031, Kota Surabaya adalah kawasan yang berfungsi sebagai PKN (Pusat Kegiatan Nasional) di Provinsi Jawa Timur dan memiliki fungsi heterogen, sehingga menjadikan Kota Surabaya sebagai pusat orientasi kegiatan penduduk yang tinggal di wilayah sekitarnya (Nuryadi, 2017).

Banyak terdapat penglaju yang beraktivitas di Kota Surabaya Setiap harinya. Berdasarkan data statistik, penglaju terbanyak berasal dari Kabupaten Sidoarjo yaitu 169.560 jiwa atau 40\% dari jumlah keseluruhan penglaju yaitu 423.109 jiwa (Statistik Komuter Gerbangkertosusila, 2017). Hal tersebut menyebabkan kemacetan dengan pola pergerakan kendaraan pribadi di wilayah Sidoarjo menuju Surabaya memiliki volume sebesar $3.491 \mathrm{smp} / \mathrm{jam}$ terutama pada jam sibuk 16.00-18.00 dengan level of service sebesar 0,90 hingga 1,58 (Masterplan Transportasi Kota Surabaya, 2017). Upaya pemerintah untuk mengurangi penggunaan kendaraan pribadi adalah menyediakan transportasi massal berupa commuter line untuk pergerakan dari Porong (Kabupaten Sidoarjo) menuju Kota Surabaya dan sebaliknya (Annisa \& Siti, 2018). Commuter line merupakan salah satu moda transportasi umum yang membawa penumpang di dalam wilayah perkotaan atau dari kota ke daerah pinggiran, biasanya kereta ini melayani pada saat jam puncak (peak hour) (Fauzi \& Palmaputri, 2015). Namun dalam memilih moda transportasi di Kabupaten Sidoarjo, hanya 1.246 jiwa atau sekitar 0,7\% dari 169.560 jiwa penglaju yang mengandalkan commuter line sedangkan jumlah pengguna kendaraanpribadi sebanyak 159.190 jiwa (Statistik Komuter Gerbangkertosusila, 2017). Commuter linerute Surabaya-Porong diperpanjang hingga Bangil per tanggal 1 Desember 2019.

Hal tersebut menunjukkan peningkatan penumpang yaitu sebesar $51 \%$ atau sebanyak 15.156 penumpang dari total 44.881 penumpang pada Bulan Januari Tahun 2020. Namun adanya pandemi covid-19 menyebabkan penurunan jumlah penumpang pada bulan April Tahun 2020 yang cukup signifikan yaitu 4.563 penumpang dari jumlah penumpang pada bulan Maret sebesar 30.897, sehingga terjadi penurunan sekitar 26.334 penumpang atau $85 \%$. Kemudian commuter line sempat mengalami pemberhentian beroperasi pada Bulan Mei akibat himbauan Pemerintah Indonesia untuk melaksanakan lockdown (Data Penumpang DAOP VIII Surabaya, 2020). Pada dokumen GAPEKA 2021 (Grafik Perjalanan Kereta Api Tahun 2021), commuter line rute Surabaya-Bangil diperpanjang kembali hingga Pasuruan dengan bekerja sama antara Daerah Operasi VIII Surabaya dan Daerah Operasi IX Jember yang mulai beroperasi per 10 Februari 2021. Commuter line rute SurabayaPasuruan dalam segi tenaga penggerak merupakan kereta api diesel yang didesain menyerupai KRL yang merupakan kereta api lokal pertama untuk relasi Surabaya-Pasuruan dan sebaliknya dikarenakan sebelumnya hanya ada kereta api jarak jauh atau antar kota. Berdasarkan data volume penumpang terdapat peningkatan penumpang sebesar $73 \%$ atau 
sebanyak 8.487 penumpang, antara bulan Januari 2021 saat masih beroperasi pada rute Surabaya-Bangil sebanyak 11.611 penumpang dengan bulan Maret 2021 saat rute Surabaya-Pasuruan dan sebaliknya telah beroperasi yaitu sebanyak 20.098 penumpang (Data Penumpang DAOP VIII Surabaya, 2021).

Terdapat berbagai permasalahan operasional maupun pelayanan commuter line rute Surabaya-Pasuruan yaitu terkait waktu tunggu penumpang tidak sesuai standar yaitu melebihi 20 menit. Kemudian pintu kereta api yang rusak sehingga dibuka manual oleh petugas dan penggunaan kursi prioritas yang tidak tepat sasaran atau digunakan oleh penumpang lainnya. Selain itu tidak tersedianya fasilitas informasi selama perjalanan melalui audio (Survei Primer, 2021).

Seiring dengan meningkatnya kebutuhan masyarakat untuk menggunakan commuter line rute Surabaya-Pasuruan, maka Daerah Operasi VIII Surabaya dan Daerah Operasi IX Jember sebagai pihak penyelenggara diharapkan mampu memberikan pelayanan yang baik serta perlu mengetahui faktor-faktor pendukung yang dapat meningkatkan kepuasan pelanggan dan juga memperbaiki faktor-faktor yang menurunkan tingkat kepuasan pelanggan. Berdasarkan uraian tersebut, maka penelitian ini penting dilakukan untuk merumuskan prioritas alternatif peningkatan kinerja operasional dan kinerja pelayanan commuter line rute Surabaya-Pasuruan dengan maksud untuk mengetahui aspek-aspek mana saja yang perlu diprioritaskan penanganannya sehingga dapat melayani penumpang secara optimal.

\section{Metode Penelitian}

Penelitian ini terdiri dari beberapa tahapan yaitu pengambilan data melalui survei primer dan sekunder untuk mengidentifikasi kinerja operasional maupun pelayanan, kemudian data tersebut dianalisis untuk menentukan prioritas arahan peningkatan kinerja operasional dan pelayanan commuter line rute Surabaya-Pasuruan (Gambar 1).

\section{Gambar 1. Kerangka Metode Penelitian}




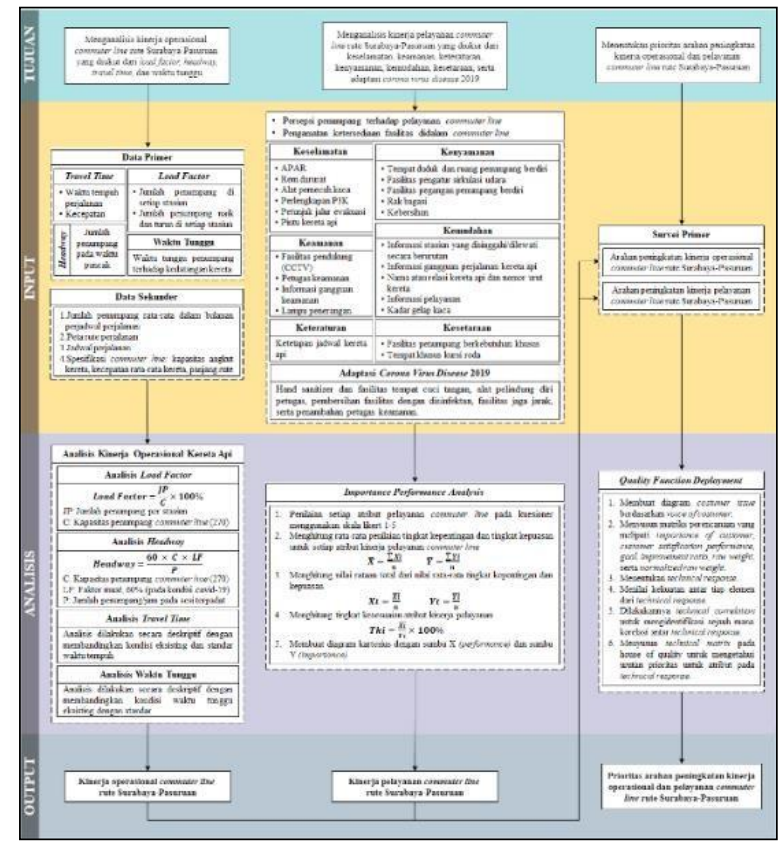

Sumber: Dokumen penulis, 2021

Penelitian ini dilakukan pada moda commuter line rute Surabaya-Pasuruan dan sebaliknya dengan 10 stasiun pemberhentian (Gambar 2). Pemilihan rute didasarkan dari jumlah penglaju di wilayah Gerbangkertosusila didominasi oleh penglaju asal Kabupaten Sidoarjo yaitu 169.560 jiwa atau $40 \%$ dari total penglaju. Selain itu, adanya perpanjangan rute Surabaya-Pasuruan menyebabkan terjadi peningkatan jumlah penumpang sebesar 73\% (Data Penumpang DAOP VIII Surabaya, 2021).

Gambar 2. Titik Stasiun Commuter Line Surabaya-Pasuruan

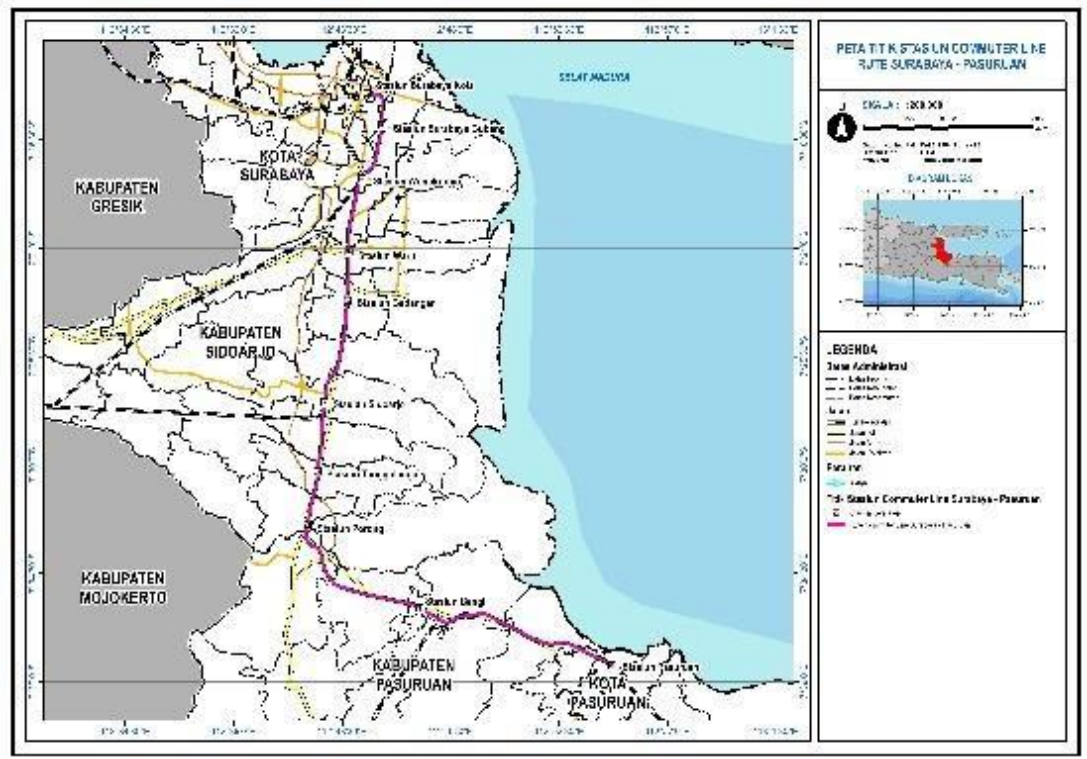


Metode pengumpulan data yang dilakukan dalam penelitian ini yaitu melalui survei primer (observasi, kuesioner, dan wawancara) serta survei sekunder (studi literatur dan survei sekunder ke salah satu instansi yaitu DAOP VIII Surabaya serta DAOP IX Jember).

\section{Analisis Kinerja Operasional}

Load factor merupakan perbandingan antara jumlah penumpang dengan kapasitas yang tersedia berupa kapasitas tempat duduk dan ruang untuk berdiri (SK. Dirjen Perhubungan Darat No 687 Tahun 2002). Berdasarkan SE No 14 Tahun 2020, pembatasan jumlah penumpang sebanyak $60 \%$ dari kapasitas penumpang saat masa pandemi covid19.

Load Factor=JP/C $\times 100 \%$

Keterangan:

$\mathrm{JP} \quad=$ Jumlah penumpang per stasiun

C = Kapasitas (270 penumpang)

Headway merupakan selang waktu antara dimana bagian depan kereta api melalui suatu titik sampai dengan saat bagian kereta api berikutnya melalui titik yang sama antara dua stasiun dan dengan satuan menit/kereta (Jamaludin, Sadili, \& Alfisyahrin, 2019). Indikator waktu headway ideal 5-10 menit dan headway puncak 2-5 menit.

Headway $=(60 \times \mathrm{C} \times \mathrm{LF}) / \mathrm{P}$

Keterangan:

C $\quad=$ Kapasitas (270 penumpang)

$\mathrm{LF} \quad=$ Load factor $60 \%$ (kondisi covid-19)

$\mathrm{P} \quad=$ Jumlah penumpang perjam pada sesi terpadat

Travel time merupakan waktu yang dibutuhkan oleh kereta untuk menempuh suatu perjalanan dari stasiun awal sampai stasiun akhir tujuan (Adika \& Osly, 2018). Menurut PM Perhubungan RI No 24 Tahun 2015, rata-rata kecepatan maksimum kereta api adalah 100 $\mathrm{km} / \mathrm{jam}$.

Waktu tunggu adalah selisih dari waktu kedatangan dengan waktu keberangkatan aktual tiap-tiap stasiun yang dilalui kereta (Sumantri \& Herijanto, 2014). Standar waktu tunggu menurut SK. Dirjen Perhubungan Darat No 687 Tahun 2002 pada setiap pemberhentian rata-rata 5-10 menit dan maksimum 10-20 menit.

\section{Metode Importance Performance Analysis}

Metode IPA dilakukan dengan tujuan untuk mengukur kepuasan yang diterima dan dianggap penting terhadap kinerja pelayanan oleh penumpang commuter line dengan menggunakan skala likert (Tabel 1).

Tabel 2. Skor Tingkat Kepentingan dan Kepuasan

\begin{tabular}{c|l|c}
\hline \multicolumn{1}{c|}{ Importance } & \multicolumn{1}{c}{ Performance } & Skor \\
\hline Sangat Tidak Penting & Sangat Tidak Memuaskan & 1 \\
\hline
\end{tabular}


JournalHomepage: http://jurnal.ut.ac.id/reksabumi https://doi.org/10.33830/Reksabumi.v1i1.2209.2022

\begin{tabular}{l|l|c}
\hline \multicolumn{1}{c|}{ Importance } & \multicolumn{1}{c}{ Performance } & Skor \\
\hline Tidak Penting & Tidak Memuaskan & 2 \\
\hline Cukup Penting & Cukup Memuaskan & 3 \\
\hline Penting & Memuaskan & 4 \\
\hline Sangat Penting & Sangat Memuaskan & 5 \\
\hline
\end{tabular}

Sumber: Ibnu dan Theresia, 2015

Dalam metode IPA, interpretasi terhadap kinerja pelayanan ditampilkan pada sebuah grafik yaitu diagram kartesius yang memiliki 4 kuadran (Gambar 3): Kuadran I (Prioritas Utama), Kuadran II (Pertahankan Prestasi), Kuadran III (Prioritas Rendah), dan Kuadran IV (Berlebihan).

\section{Gambar 3. Diagram Kartesius}

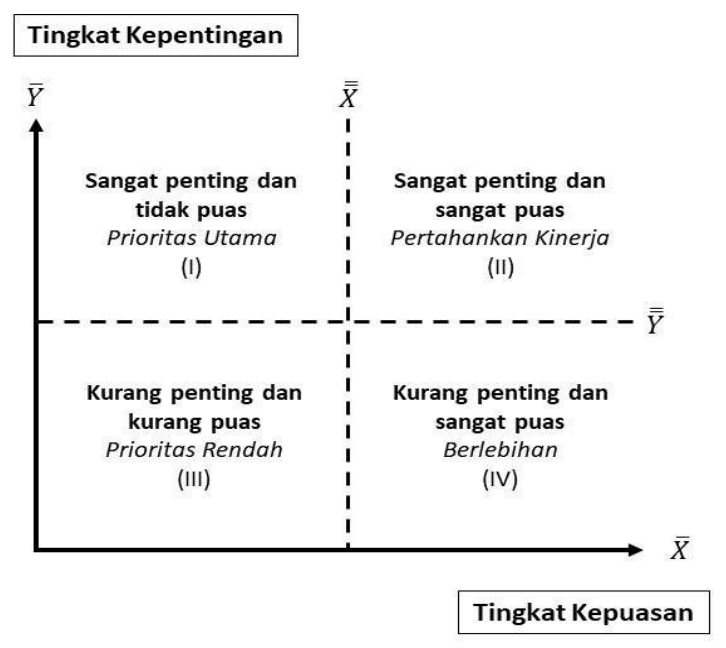

Sumber: Trisna, Irwansyah, Saptari, \& Maisyaroh, 2019

\section{Metode Quality Function Deployment}

Metode QFD digunakan untuk menentukan prioritas arahan peningkatan kualitas kinerja operasional dan pelayanan commuter line berdasarkan permintaan penumpang yang digambarkan dalam House of Quality.

\section{PEMBAHASAN}

\section{Karakteristik Moda Commuter Line Rute Surabaya-Pasuruan}

Commuter line rute Surabaya-Pasuruan merupakan moda kereta yang berada dalam naungan kerjasama antara Daerah Operasi VIII Surabaya dengan Daerah Operasi IX Jember yang beroperasi per tanggal 10 Februari 2021. Commuter line ini merupakan perpanjangan rute perjalanan dari sebelumnya yaitu rute Surabaya-Porong dan rute Surabaya-Bangil. Commuter line rute Surabaya-Pasuruan terdiri dari 4 gerbong dengan 
kapasitas sebesar 270 penumpang (Gerbong 1 dan 4 sebanyak 64; gerbong 2 sebanyak 70; serta gerbong 3 sebanyak 72).

\section{Rute Perjalanan}

Stasiun pemberhentian pada commuter line rute Surabaya-Pasuruan adalah sebanyak 10 stasiun, yaitu Stasiun Surabaya Kota, Stasiun Surabaya Gubeng, Stasiun Wonokromo, Stasiun Waru, Stasiun Gedangan, Stasiun Sidoarjo, Stasiun Tanggulangin, Stasiun Porong, Stasiun Bangil, dan Stasiun Pasuruan.

\section{Jadwal Perjalanan}

Jumlah perjalanan pada commuter line rute Surabaya-Pasuruan dan sebaliknya masingmasing 3 jadwal perjalanan: KA 681, KA 683 dan KA 685.

\section{Sistem Tiket dan Tarif}

Sistem pembelian tiket commuter line rute Surabaya-Pasuruan yaitu langsung pada loket stasiun dan melalui aplikasi KAI Access, dengan besar tarif tiket sebesar Rp 6.000. Tarif tiket ini merupakan tarif flat jauh-dekat, berarti seberapa jauh perjalanan dikenakan tarif yang sama.

\section{Volume Penumpang}

Tabel 2 merupakan stastistik penumpang commuter line rute Surabaya-Pasuruan.

Tabel 2. Statistik Penumpang Commuter Line Rute Surabaya-Pasuruan Bulan Februari-April Tahun 2021

\begin{tabular}{|c|c|c|c|c|}
\hline \multirow{2}{*}{\multicolumn{2}{|c|}{ Rute Perjalanan }} & \multicolumn{3}{|c|}{ Bulan } \\
\hline & & Februari & Maret & April \\
\hline \multirow{3}{*}{$\begin{array}{l}\text { Surabaya- } \\
\text { Pasuruan }\end{array}$} & KA 681 & 111 & 255 & 322 \\
\hline & KA 683 & 2.455 & 4.470 & 3.789 \\
\hline & KA 685 & 2.121 & 4.283 & 4.114 \\
\hline \multirow{3}{*}{$\begin{array}{l}\text { Pasuruan- } \\
\text { Surabaya }\end{array}$} & KA 682 & 3.957 & 6.582 & 5.981 \\
\hline & KA 684 & 1.994 & 3.879 & 3.382 \\
\hline & KA 686 & 308 & 629 & 728 \\
\hline \multicolumn{2}{|c|}{ Total } & 10.946 & 20.098 & 18.316 \\
\hline
\end{tabular}

Sumber: Daerah Operasi VIII Surabaya, 2021

\section{B. Karakteristik Penumpang Commuter Line Rute Surabaya-Pasuruan}

Karakteristik penumpang diperoleh dari hasil kuesioner yang telah dilakukan pada penumpang commuter line rute Surabaya-Pasuruan melalui kuesioner online. Adapun sampel yang digunakan untuk kuesioner ini adalah sebanyak 397 sampel dengan metode slovin. Karakteristik penumpang commuter line rute Surabaya-Pasuruan terbagi atas usia, jenis pekerjaan, maksud perjalanan, dan intensitas perjalanan. Kegunaan data karakteristik ini adalah sebagai pertimbangan dalam tahap analisis maupun dalam penentuan prioritas arahan, seperti pada kelompok usia sebagai penentuan kapasitas kursi prioritas. Selain itu jenis pekerjaan, maksud pekerjaan, dan intensitas perjalanan juga sebagai pertimbangan 
penentuan jadwal maupun tinjauan waktu tunggu/waktu perjalanan guna meningkatkan ketepatan waktu.

\section{Karakteristik Berdasarkan Usia}

Adanya penumpang berusia 45 tahun keatas yang dikategorikan sebagai penumpang lansia (lanjut usia) yaitu sebesar $5 \%$ menunjukkan penggunaan kursi prioritas seharusnya sudah memadahi dalam pelayanannya, namun saat melakukan survei observasi masih banyak ditemui penggunaan kursi prioritas yang tidak tepat sasaran.

\section{Karakteristik Berdasarkan Jenis Pekerjaan}

Mayoritas penumpang dengan jenis pekerjaan pelajar/mahasiswa dan karyawan swasta memiliki jam kehadiran yang pasti, sehingga sangat mementingkan ketepatan waktu. Oleh karena itu perlu dilakukan peninjauan dan perencanaan terkait jadwal perjalanan dan ketepatan waktu.

\section{Karakteristik Berdasarkan Maksud Perjalanan}

Adapun penumpang dengan tujuan berkunjung biasanya melakukan perjalanan saat weekend (hari libur), sedangkan penumpang dengan tujuan bekerja adalah saat weekdays (hari kerja). Adanya kedua tipe tujuan tersebut dapat dijadikan sebagai acuan perencanaan pengembangan commuter line, seperti pada kualitas pelayanan dan ketepatan waktu bagi penumpang dengan maksud perjalanan bekerja.

\section{Karakteristik Berdasarkan Intensitas Perjalanan}

Alasan banyaknya penumpang yang memiliki intensitas perjalanan tidak tentu karena menggunakan commuter line untuk berkunjung dan jalan-jalan. Penumpang dengan intensitas perjalanan yang tidak tentu disebut sebagai penumpang tidak tetap yaitu penumpang yang melakukan perjalanan saat waktu dan kondisi tertentu.

\section{Kinerja Operasional Commuter Line Rute Surabaya-Pasuruan}

Evaluasi kinerja operasional dilakukan pada hari dan waktu puncak pergerakan. Penentuan hari tersebut yaitu hari Jumat mewakili hari kerja (KRD 685) dan hari Minggu mewakili hari libur (KRD 683) untuk rute Surabaya-Pasuruan, serta hari Senin mewakili hari kerja (KRD 682) dan hari Minggu (KRD 684) mewakili hari libur untuk rute PasuruanSurabaya.

\section{Load Factor}

Perhitungan load factor adalah membandingkan volume jumlah penumpang dengan kapasitas tempat duduk penumpang kereta, hal tersebut dikarenakan penelitian dilakukan saat masa pandemi covid-19 yang mengharuskan penumpang satu sama lain menghindari kontak fisik sehingga kapasitas ruang penumpang berdiri tidak dihitung.

1. Rute Surabaya-Pasuruan

Adapun hasil perhitungan load factor rute Surabaya-Pasuruan dijabarkan dalam Tabel 3.

Tabel 3. Load Factor Rute Surabaya-Pasuruan

\begin{tabular}{c|l|c|c|c|c|c}
\hline Nomor Kereta & Stasiun & $\begin{array}{c}\text { Penumpang } \\
\text { Naik }\end{array}$ & $\begin{array}{c}\text { Penumpang } \\
\text { Turun }\end{array}$ & Volume & $\mathbf{C}$ & LF \\
\hline Hari Kerja & Surabaya Kota & 32 & 0 & 32 & 270 & $12 \%$ \\
\cline { 2 - 7 } KRD 685 & Surabaya Gubeng & 67 & 0 & 99 & 270 & $37 \%$ \\
\hline
\end{tabular}




\begin{tabular}{|c|c|c|c|c|c|c|}
\hline Nomor Kereta & Stasiun & $\begin{array}{c}\text { Penumpang } \\
\text { Naik }\end{array}$ & $\begin{array}{c}\text { Penumpang } \\
\text { Turun }\end{array}$ & Volume & C & LF \\
\hline & Wonokromo & 46 & 0 & 145 & 270 & $54 \%$ \\
\hline & Waru & 23 & 7 & 161 & 270 & $60 \%$ \\
\hline & Gedangan & 3 & 11 & 153 & 270 & $57 \%$ \\
\hline & Sidoarjo & 9 & 39 & 123 & 270 & $46 \%$ \\
\hline & Tanggulangin & 0 & 15 & 108 & 270 & $40 \%$ \\
\hline & Porong & 1 & 9 & 100 & 270 & $37 \%$ \\
\hline & Bangil & 0 & 43 & 57 & 270 & $21 \%$ \\
\hline & Pasuruan & 0 & 57 & 0 & 270 & $0 \%$ \\
\hline & \multicolumn{5}{|c|}{ Rata-rata } & $40 \%$ \\
\hline \multirow{11}{*}{$\begin{array}{c}\text { Hari Libur } \\
\text { KRD } 683\end{array}$} & Surabaya Kota & 47 & 0 & 47 & 270 & $17 \%$ \\
\hline & Surabaya Gubeng & 38 & 0 & 85 & 270 & $31 \%$ \\
\hline & Wonokromo & 64 & 0 & 149 & 270 & $55 \%$ \\
\hline & Waru & 11 & 2 & 158 & 270 & $59 \%$ \\
\hline & Gedangan & 19 & 5 & 172 & 270 & $64 \%$ \\
\hline & Sidoarjo & 23 & 34 & 161 & 270 & $60 \%$ \\
\hline & Tanggulangin & 1 & 15 & 147 & 270 & $54 \%$ \\
\hline & Porong & 0 & 9 & 138 & 270 & $51 \%$ \\
\hline & Bangil & 0 & 47 & 91 & 270 & $34 \%$ \\
\hline & Pasuruan & 0 & 47 & 0 & 270 & $0 \%$ \\
\hline & & & & & a-rata & $47 \%$ \\
\hline
\end{tabular}

Sumber: Dokumen penulis, 2021

Rata-rata load factor rute Surabaya-Pasuruan pada saat hari kerja dan hari libur masing-masing sebesar $40 \%$ dan $47 \%$. Hasil analisis tersebut menunjukkan bahwa terjadi peningkatan jumlah penumpang pada saat hari kerja di Stasiun Surabaya Kota hingga puncaknya pada Stasiun Waru yang mencapai load factor maksimal yaitu sebesar $60 \%$. Hal tersebut dikarenakan karakteristik maksud perjalanan ini adalah didominasi oleh para pekerja yang hendak pulang ke daerah asal yaitu Sidoarjo dan Pasuruan. Sedangkan pada saat hari libur terjadi peningkatan jumlah penumpang yang signifikan di Stasiun Wonokromo dengan puncaknya di Stasiun Gedangan yaitu sebesar 64\% (melebihi standar maksimal load factor yaitu 60\%). Hal tersebut dikarenakan karakteristik maksud perjalanan pada saat hari libur didominasi oleh penumpang yang hendak pulang ataupun berkunjung ke daerah Sidoarjo dan Pasuruan.

\section{Rute Pasuruan-Surabaya}

Rute Pasuruan-Surabaya memiliki rata-rata load factor pada saat hari kerja dan hari libur masing-masing adalah sebesar 57\% dan 47\%. Dari hasil analisis tersebut menunjukkan bahwa terjadi peningkatan jumlah penumpang pada saat hari kerja di stasiun awal yaitu Stasiun Pasuruan hingga puncaknya pada Stasiun Sidoarjo dan Stasiun Gedangan yang mencapai load factor yaitu sebesar 83\% (melebihi standar maksimal load factor yaitu 60\%). Hal tersebut dikarenakan karakteristik maksud perjalanan ini adalah didominasi oleh para pekerja yang melakukan perjalanan ke tempat kerja di Kota Surabaya. Sedangkan pada saat hari libur terjadi peningkatan jumlah penumpang di stasiun awal yaitu Stasiun Pasuruan dengan puncaknya di Stasiun Waru yaitu sebesar 66\% (melebihi standar maksimal load factor yaitu 60\%). Hal tersebut dikarenakan karakteristik maksud perjalanan pada saat hari libur didominasi oleh penumpang yang hendak berkunjung ke Kota Surabaya. 


\section{Headway}

Headway digunakan untuk mengetahui kebutuhan jumlah perjalanan dalam rute Surabaya-Pasuruan dan sebaliknya dalam rentang waktu yang ditentukan. Waktu headway ideal berdasarkan SK. Dirjen Perhubungan Darat No 687 Tahun 2002 adalah 5 menit sampai 10 menit dengan headway puncak adalah 2 menit sampai 5 menit. Nilai load factor yang digunakan dalam analisis ini adalah nilai load factor maksimum yaitu $60 \%$.

1. Rute Surabaya-Pasuruan

Headway ideal commuter line rute Surabaya-Pasuruan berkisar antara 884 hingga 48 menit yang masih dapat memenuhi kebutuhan penumpang dengan jumlah penumpang yang tidak melebihi kapasitas yang ada. Besarnya angka headway ideal pada jadwal 03.01 WIB sampai 04.00 WIB disebabkan sistem commuter line rute Surabaya-Pasuruan adalah kereta pergi-pulang dari Stasiun Surabaya Kota, sehingga jadwal keberangkatan 03.10 WIB digunakan untuk menjemput penumpang di Stasiun Pasuruan yang selanjutnya kembali dengan rute Pasuruan-Surabaya pada jadwal keberangkatan 05.35 WIB karena kereta tidak menginap di Stasiun Pasuruan. Adapun jam puncak pada rute Surabaya-Pasuruan saat hari kerja adalah pada jam 18.01-19.00 WIB, karena karakteristik penumpangnya didominasi oleh para pekerja yang hendak pulang ke daerah asal yaitu Sidoarjo dan Pasuruan. Sedangkan jam puncak saat hari libur pada jam 11.01-12.00 WIB, karena karakteristik penumpangnya didominasi oleh penumpang yang hendak pulang ataupun berkunjung ke daerah Sidoarjo dan Pasuruan. Maka berdasarkan hasil perhitungan headway sudah dapat memenuhi kebutuhan penumpang pada jam puncak, sehingga penambahan gerbong ataupun jam keberangkatan untuk memenuhi kebutuhan penumpang pada rute SurabayaPasuruan masih belum dibutuhkan karena tidak melebihi kapasitas.

2. Rute Pasuruan-Surabaya Hasil perhitungan headway pada rute Pasuruan-Surabaya dijabarkan dalam Tabel 4. Tabel 4. Headway Rute Pasuruan-Surabaya

\begin{tabular}{c|c|c|c|c|c|c|c}
\hline \multicolumn{2}{c|}{ Waktu } & $\begin{array}{c}\text { Jumlah } \\
\text { Armada }\end{array}$ & $\begin{array}{c}\text { HW } \\
\text { Eksisting }\end{array}$ & C & LF & F & $\begin{array}{c}\text { HW } \\
\text { Ideal }\end{array}$ \\
\hline \multirow{2}{*}{$\begin{array}{l}\text { Hari Kerja } \\
\text { (weekday) }\end{array}$} & $05.01-06.00$ & 1 & 60 & 270 & 0,6 & 258 & 38 \\
\cline { 2 - 8 } & $15.01-16.00$ & 1 & 60 & 270 & 0,6 & 117 & 83 \\
\cline { 2 - 8 } & $21.01-22.00$ & 1 & 60 & 270 & 0,6 & 165 & 59 \\
\hline \multirow{2}{*}{$\begin{array}{c}\text { Hari Libur } \\
\text { (weekend) }\end{array}$} & $05.01-06.00$ & 1 & 60 & 270 & 0,6 & 193 & 50 \\
\cline { 2 - 8 } & $15.01-16.00$ & 1 & 60 & 270 & 0,6 & 211 & 46 \\
\cline { 2 - 8 }
\end{tabular}

Sumber: Dokumen penulis, 2021

Headway ideal commuter line rute Pasuruan-Surabaya berkisar antara 83 hingga 38 menit yang masih dapat memenuhi kebutuhan penumpang dengan jumlah penumpang yang tidak melebihi kapasitas yang ada. Adapun jam puncak pada rute Pasuruan-Surabaya saat hari kerja adalah pada jam 05.01-06.00 WIB, karena karakteristik penumpangnya didominasi oleh para pekerja yang melakukan perjalanan ke tempat kerja di Kota Surabaya. Sedangkan jam puncak saat hari libur pada jam 15.01-16.00 WIB, karena karakteristik penumpangnya didominasi oleh penumpang yang hendak berkunjung ke Kota Surabaya. Berdasarkan hasil perhitungan headway sudah dapat memenuhi kebutuhan penumpang pada jam puncak, sehingga penambahan gerbong ataupun jam keberangkatan untuk 
memenuhi kebutuhan penumpang pada rute Pasuruan-Surabaya masih belum dibutuhkan karena tidak melebihi kapasitas.

\section{Travel Time}

Tujuan perhitungan travel time untuk mengetahui di stasiun mana commuter line mengalami penurunan kecepatan yang hal tersebut dapat berdampak pada keterlambatan jadwal kereta api.

1. Rute Surabaya-Pasuruan

Travel time total yaitu waktu tempuh yang dijumlahkan dengan waktu tunggu penumpang berdasarkan jadwal perjalanan untuk KRD 685 adalah selama 2 jam 13 menit dengan waktu tempuh selama 85 menit. Sedangkan pada KRD 683 travel time total selama 2 jam 27 menit dengan waktu tempuh 85 menit.

Penurunan kecepatan kereta disebabkan oleh jarak stasiun yang cukup dekat seperti Stasiun Surabaya Kota dan Stasiun Surabaya Gubeng, serta adanya antrian kereta pada stasiun tujuan. Berdasarkan jadwal perjalanan, diketahui bahwa travel time ideal dari commuter line rute Surabaya-Pasuruan adalah 85 menit. Hal tersebut menunjukkan kinerja operasional commuter line rute Surabaya-Pasuruan dalam aspek travel time dapat dikatakan sudah memenuhi standar dari segi kecepatan dan ketepatan waktu.

\section{Rute Pasuruan-Surabaya}

Travel time total berdasarkan jadwal perjalanan untuk KRD 682 pada saat hari kerja adalah selama 2 jam 3 menit dengan waktu tempuh perjalanan kereta adalah selama 83 menit. Sedangkan travel time total pada KRD 684 saat hari libur adalah selama 2 jam 42 menit dengan waktu tempuh perjalanan selama 86 menit.

Berdasarkan jadwal perjalanan, diketahui bahwa travel time ideal dari commuter line rute Pasuruan-Surabaya saat hari kerja dan hari libur masing-masing adalah 83 menit dan 86 menit. Hal tersebut menunjukkan kinerja operasional commuter line rute PasuruanSurabaya dalam aspek travel time dapat dikatakan sudah memenuhi standar dari segi kecepatan dan ketepatan waktu.

\section{Waktu Tunggu}

Waktu tunggu digunakan untuk menghitung selisih waktu kedatangan dan keberangkatan kereta di setiap pemberhentian stasiun dalam satuan menit.

\section{Rute Surabaya-Pasuruan}

Berdasarkan jadwal perjalanan, total waktu tunggu KRD 685 di setiap pemberhentian stasiun adalah selama 48 menit, sedangkan pada KRD 683 adalah selama 62 menit.

Total keseluruhan waktu tunggu rute Surabaya-Pasuruan hari kerja dan hari libur di 8 pemberhentian stasiun masing-masing selama 58 menit 37 detik dan 79 menit 26 detik. Hal tersebut berarti mengalami keterlambatan keberangkatan selama 10 menit pada hari kerja ( $8 \%$ dari total waktu tunggu) dan 17 menit pada hari libur (12\% dari total waktu tunggu). Maka hal tersebut menunjukkan rute Surabaya-Pasuruan dalam aspek waktu tunggu sudah memenuhi standar, karena keterlambatan waktu tunggu tidak melebih $20 \%$ dari total waktu tempuh. Namun jadwal di hari libur pada rute Surabaya-Pasuruan, waktu tunggu di Stasiun Sidoarjo tidak sesuai standar yaitu melebih 20 menit maksimal waktu tunggu. Berdasarkan data GAPEKA 2021, commuter line rute Surabaya-Pasuruan pada KRD 683 bersilangan 
dengan kereta api Sritanjung (kereta kelas ekonomi) dengan rute Banyuwangi-Yogyakarta di Stasiun Sidoarjo dengan waktu kedatangan 12.31 WIB hingga 12.34 WIB.

1. Rute Pasuruan-Surabaya

Total waktu tunggu berdasarkan jadwal perjalanan pada KRD 682 di setiap pemberhentian stasiun adalah selama 43 menit, sedangkan pada KRD 684 adalah selama 76 menit.

Keseluruhan waktu tunggu rute Pasuruan-Surabaya hari kerja dan hari libur di 8 pemberhentian stasiun masing-masing selama 43 menit 13 detik dan 80 menit 33 detik. Hal tersebut berarti kereta mengalami keterlambatan keberangkatan selama 3 menit pada hari kerja ( $2 \%$ dari total waktu tunggu) dan 4 menit pada hari libur ( $2 \%$ dari total waktu tunggu). Maka hal tersebut menunjukkan rute Pasuruan-Surabaya dalam aspek waktu tunggu sudah memenuhi standar, karena keterlambatan waktu tunggu tidak melebih $20 \%$ dari total waktu tempuh. Namun jadwal di hari libur pada rute Pasuruan-Surabaya, waktu tunggu di Stasiun Bangil tidak sesuai standar yaitu melebih 20 menit maksimal waktu tunggu. Berdasarkan data GAPEKA 2021, commuter line rute Pasuruan-Surabaya pada KRD 684 bersilangan dengan kereta api Logawa (kereta kelas bisnis dan ekonomi) dengan rute PurwokertoSurabaya Gubeng-Jember di Stasiun Bangil dengan waktu kedatangan 15.33 WIB hingga 15.37 WIB.

\section{Kinerja Pelayanan Commuter Line Rute Surabaya-Pasuruan}

Evaluasi kinerja pelayanan dilakukan mengacu pada pada PM Perhubungan No 63 Tahun 2019 serta SE No 14 Tahun 2020. Aspek-aspek yang dinilai untuk kinerja pelayanan antara lain keselamatan, keamanan, kenyamanan, kehandalan, kemudahan, kesetaraan, serta adaptasi Corona Virus Disease 2019.

\section{Fasilitas Pelengkap Commuter Line}

Sebelum menghitung tingkat kepuasan dan kepentingan dengan metode IPA terhadap kinerja pelayanan, maka dilakukan pengamatan terlebih dahulu untuk mengetahui kondisi eksisting pelayanan commuter line yang terdiri dari 25 aspek pelayanan.

\section{Gambar 4. Diagram Kartesius IPA}

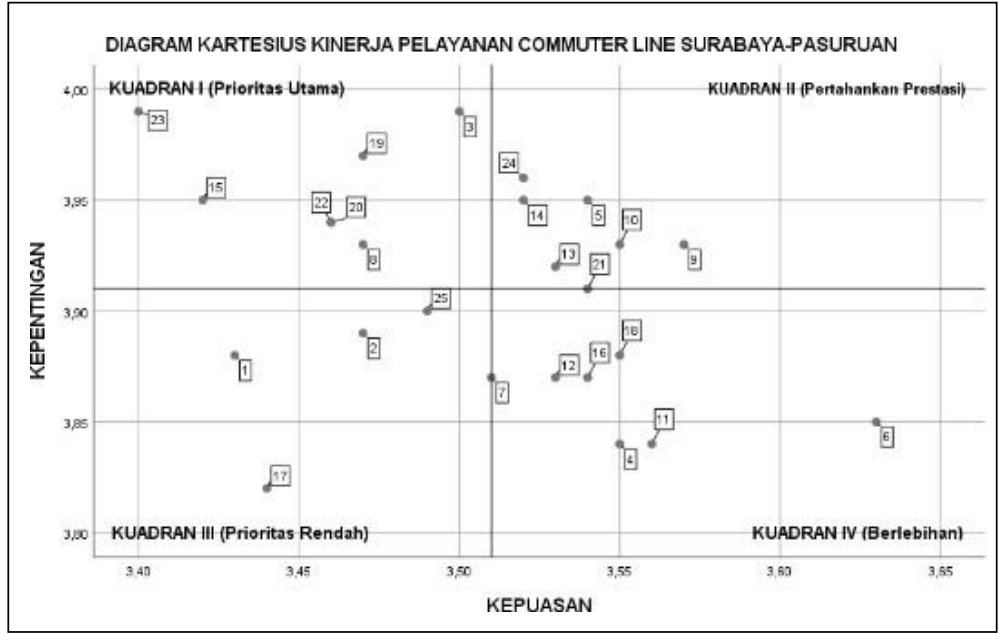

Sumber: Dokumen penulis, 2021 
Berdasarkan diagram pada Gambar 5 menunjukkan pengelompokkan atribut kinerja pelayanan di keempat kuadran IPA. Rincian atribut pelayanan dalam kuadran IPA adalah kuadran I terdiri dari 7 atribut, kuadran II terdiri dari 7 atribut, kuadran III terdiri dari 4 atribut dan kuadran IV terdiri dari 7 atribut. Klasifikasi detil terkait atribut dari masing-masing kuadran bisa dilihat pada Tabel 5 .

Tabel 5. Klasifikasi Atribut Pelayanan Dalam Kuadran IPA

\begin{tabular}{|c|c|c|}
\hline Kuadran & & Atribut Pelayanan \\
\hline \multirow{7}{*}{$\begin{array}{c}\text { Kuadran I } \\
\text { Prioritas Utama }\end{array}$} & 3 & Pintu kereta \\
\hline & 8 & Keteraturan jadwal kereta api \\
\hline & 15 & Informasi gangguan perjalanan kereta \\
\hline & 19 & Fasilitas penumpang berkebutuhan khusus \\
\hline & 20 & Ketersediaan tempat khusus kursi roda \\
\hline & 22 & Fasilitas jaga jarak (1 meter) \\
\hline & 23 & Pembersihan fasilitas dengan disinfektan oleh petugas OTC \\
\hline \multirow{7}{*}{$\begin{array}{c}\text { Kuadran II } \\
\text { Pertahankan } \\
\text { Prestasi }\end{array}$} & 5 & Petugas keamanan \\
\hline & 9 & Tempat duduk penumpang dengan sandaran \\
\hline & 10 & Fasilitas pengatur sirkulasi udara \\
\hline & 13 & Kebersihan \\
\hline & 14 & Informasi rute kereta \\
\hline & 21 & Fasilitas hand sanitizer dan tempat cuci tangan \\
\hline & 24 & Petugas sesuai protokol kesehatan \\
\hline \multirow{4}{*}{$\begin{array}{c}\text { Kuadran III } \\
\text { Prioritas Rendah }\end{array}$} & 1 & Informasi dan fasilitas keselamatan \\
\hline & 2 & Informasi dan fasilitas kesehatan \\
\hline & 17 & Informasi pelayanan perjalanan kereta \\
\hline & 25 & Penambahan petugas keamanan \\
\hline \multirow{7}{*}{$\begin{array}{l}\text { Kuadran IV } \\
\text { Berlebihan }\end{array}$} & 4 & Ketersediaan CCTV \\
\hline & 6 & Informasi gangguan keamanan \\
\hline & 7 & Lampu penerangan \\
\hline & 11 & Fasilitas pegangan penumpang berdiri \\
\hline & 12 & Rak bagasi \\
\hline & 16 & Nama/relasi kereta \\
\hline & 18 & Kadar gelap kaca film \\
\hline
\end{tabular}

Sumber: Dokumen penulis, 2021

\section{Prioritas Alternatif Peningkatan Kinerja Commuter line}

Penilaian pada kinerja operasional diasumsikan menggunakan skala likert yaitu 1-5 yang disesuaikan dengan penilaian kinerja pelayanan. Asumsi penilaian kepuasan kinerja operasional ditentukan sendiri berdasarkan hasil masing-masing analisis dengan rincian nilai load factor - 3, headway - 4, travel time - 4, dan waktu tunggu - 3. Sedangkan untuk nilai kepentingan kinerja operasional diasumsikan memiliki nilai 5, hal tersebut dikarenakan keempat variabel kinerja operasional dianggap sangat penting dan saling berpengaruh. Berikut merupakan respon teknis dari kinerja operasional:

1. Penambahan gerbong kereta api

2. Perawatan dan pemeriksaan sarana perkeretaapian secara berkala

Berdasarkan perhitungan dengan metode IPA untuk mengetahui tingkat kepuasan dan kepentingan dari presepsi penumpang didapatkan 7 atribut kinerja pelayanan yang termasuk dalam kuadran I (prioritas utama). Adapun ketujuh atribut tersebut adalah pintu 
JournalHomepage: $\underline{\text { http://jurnal.ut.ac.id/reksabumi https://doi.org/10.33830/Reksabumi.v1i1.2209.2022 }}$

kereta, keteraturan jadwal kereta api, informasi gangguan perjalanan, fasilitas penumpang berkebutuhan khusus, tempat khusus kursi roda, fasilitas jaga jarak, serta pembersihan fasilitas dengan disinfektan oleh petugas OTC. Berikut merupakan respon teknis dari kinerja pelayanan:

1. Perawatan dan pemeriksaan sarana perkeretaapian secara berkala

2. Penyediaan informasi kereta dalam bentuk audio

3. Penyediaan portable ramp

4. Penyediaan tempat khusus kursi roda

5. Penambahan gerbong kereta api

6. Pembersihan fasilitas kereta menggunakan disinfektan

Gambar 5. House of Quality Kinerja Pelayanan

\begin{tabular}{|c|c|c|c|c|c|c|c|c|c|c|c|c|c|c|}
\hline \multirow[t]{2}{*}{$\begin{array}{l}\text { HOUSE OF QUALITY } \\
\text { Kinerja Operasional \& Pelayan } \\
\text { Commuter Line } \\
\text { Rute Surabaya-Pasuruan }\end{array}$} & \multirow[t]{2}{*}{ + } & \multirow{2}{*}{$\underset{\tilde{\alpha}}{\tilde{\alpha}}$} & \multirow{2}{*}{$\stackrel{m}{a}$} & \multirow{2}{*}{ 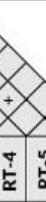 } & \multirow{2}{*}{\multicolumn{2}{|c|}{$\stackrel{\substack{\alpha \\
\alpha}}{\stackrel{L}{\alpha}}$}} & \multicolumn{8}{|c|}{$\begin{array}{l}\text { Keterangan: } \\
\text { RT-1: Perawatan dan perbaikan sarana perkeretaapian } \\
\text { secara berkala } \\
\text { RT-2: Penyediaan informasi kereta dalam bentuk audio } \\
\text { RT-3: Penyediaan portabie ramp } \\
\text { RT-4: Penyediaan tempat khusus kursi roda } \\
\text { RT-5: Penambahan gerbong kereta api } \\
\text { RT-6: Pembersihan fasilitas kereta menggunakan disinfektan }\end{array}$} \\
\hline & & & & & & & CSP & Goal & NK & NH & loc & IR & RW & NRW \\
\hline Load Factor & & & & & $\bullet$ & & 3,00 & 5,00 & - & - & 0,250 & 0,600 & 3,00 & 0.214 \\
\hline Waktu Tunggu & $\bullet$ & - & & & 0 & - & 3,00 & 5,00 & - & - & 0.250 & 0.600 & 3.00 & 0,214 \\
\hline Headway & & & & & $\bullet$ & & 4,00 & 5,00 & + & - & 0,250 & 0,800 & 4,00 & 0.286 \\
\hline Travel Time & - & & & & & - & 4,00 & 5.00 & - & - & 0.250 & 0,800 & 4,00 & 0,286 \\
\hline Pembersihan fasilitas & & & & & & $\bullet$ & 3.40 & 3,99 & 1.350 & 1.585 & 0,144 & 0.852 & 3,40 & 0,141 \\
\hline Informasi gangguan perjalanan & $\Delta$ & $\bullet$ & & & & & 3,42 & 3,95 & 1.357 & 1.567 & 0,143 & 0,866 & 3,42 & 0,141 \\
\hline Fasilitas penumpang difabel & $\Delta$ & & $\bullet$ & $\bullet$ & & & 3,47 & 3,97 & 1.377 & 1.576 & 0,143 & 0,874 & 3,47 & 0,144 \\
\hline Pintu kereta & - & & & & & & 3,50 & 3,99 & 1.388 & 1.583 & 0,144 & 0,877 & 3,50 & 0.145 \\
\hline Tempat khusus kursi roda & $\Delta$ & & $\bullet$ & $\bullet$ & & & 3,46 & 3,94 & 1.372 & 1.563 & 0,142 & 0,878 & 3,46 & 0,143 \\
\hline Fasilitas jaga jarak (1 meter) & & & & & - & & 3,46 & 3,94 & 1.372 & 1.566 & 0,142 & 0,878 & 3,46 & 0,143 \\
\hline Ketepatan jadwal kereta & $\bullet$ & $\bullet$ & & & & $\bullet$ & 3.47 & 3,93 & 1.379 & 1.560 & \begin{tabular}{|l|}
0.142 \\
\end{tabular} & 0,883 & 3,47 & 0,144 \\
\hline $\mathrm{N}$ & 15 & 9 & 6 & 6 & 11 & 12 & & chnical C & Correlati & & & elationshil & hip Matri & \\
\hline Cont & 6,45 & 1.71 & 1,72 & 1.72 & 0.43 & 1.14 & & (+) Sang & gat Kuat & & & & & \\
\hline NC & 0,46 & 0,09 & 0,03 & 0,03 & 0,19 & 0,19 & & $\begin{array}{l}\text { (t) Cukk } \\
\text { Tidak A }\end{array}$ & $\begin{array}{l}\text { up Kuat } \\
\text { Ida Pens }\end{array}$ & uh & & $\Delta$ & Lemah & \\
\hline AI & 21,96 & 4,81 & 171 & 1.71 & 9,81 & 9.43 & $\bar{x}$ & $\leftrightarrow \rightarrow$ Cukn & up Kuat & & & $\begin{array}{ll}2 & 5 \\
3 & k\end{array}$ & $\begin{array}{l}\text { Sedang } \\
\text { Kuat }\end{array}$ & \\
\hline PRIORITAS & 1 & 4 & 5 & 6 & 2 & 3 & & & & & & & & \\
\hline
\end{tabular}

Sumber: Dokumen penulis, 2021

Berdasarkan hasil analisis QFD maka nilai absolute importance atau nilai kepentingan yang didapatkan dari nilai hubungan antara aspek yang diprioritaskan oleh penumpang dengan respon teknis serta nilai harapan dari penumpang commuter line rute SurabayaPasuruan. Prioritas arahan respon teknis didasarkan pada nilai absolute importance, berikut merupakan nilai absolute importance serta urutan prioritas penanganan kinerja operasional dan pelayanan dari hasil analisis QFD yang dijabarkan dalam Tabel 6.

Tabel 6. Prioritas Penanganan Kinerja Operasional dan Pelayanan Commuter Line Rute Surabaya-Pasuruan

\begin{tabular}{clcc}
\hline RT & \multicolumn{1}{c}{ Technical Response } & Al & Prioritas \\
\hline 1 & Perawatan dan perbaikan sarana perkeretaapian secara berkala & 21,96 & 1 \\
\hline 5 & Penambahan gerbong kereta api & 9,81 & 2 \\
\hline 6 & Pembersihan fasilitas kereta menggunakan disinfektan & 9,43 & 3 \\
\hline 2 & Penyediaan informasi kereta dalam bentuk audio & 4,81 & 4 \\
\hline 3 & Penyediaan portable ramp & 1,71 & 5 \\
\hline 4 & Penyediaan tempat khusus kursi roda & 1,71 & 6 \\
\hline
\end{tabular}

Sumber: Dokumen penulis, 2021 
Berdasarkan hasil perhitungan dalam analisis QFD pada Gambar 5 dan Tabel 6 didapatkan bahwa prioritas arahan respon teknis kinerja operasional dan pelayanan adalah perawatan dan pemeriksaan sarana perkeretaapian secara berkala dengan nilai absolute importance 21,96.

\section{KESIMPULAN}

Load factor pada ketiga jadwal antara lain rute Surabaya-Pasuruan hari libur serta rute Pasuruan Surabaya hari kerja dan hari libur telah melebihi standar pembatasan nilai ratarata kapasitas angkut sebesar $60 \%$. Berdasarkan perhitungan headway sudah dapat memenuhi kebutuhan penumpang jam puncak karena tidak melebihi kapasitas. Selain itu terdapat commuter line rute Surabaya-Sidoarjo-Bangil dan sebaliknya yang memiliki jadwal perjalanan yang berdekatan dengan commuter line rute Surabaya-Pasuruan dansebaliknya, sehingga menjadi salah satu alternatif dalam mengatasi kebutuhan penumpangsaat jam puncak. Travel time eksisting rute Surabaya-Pasuruan dan sebaliknya juga telah sesuai dengan travel time ideal pada jadwal keberangkatan kereta dan kecepatan rata-ratasudah sesuai dengan standar (maksimal $100 \mathrm{~km} / \mathrm{jam}$ ) yaitu antara 46,94 km/jam sampai 51,06 $\mathrm{km} / \mathrm{jam}$. Waktu tunggu pada beberapa pemberhentian stasiun tidak sesuai standar yaitu 22 menit yang melebihi 20 menit maksimal waktu tunggu. Keterlambatan keberangkatan berkisar 3-17 menit yang dipersentasekan sebesar 2\% sampai 12\% dari total waktu tempuh perjalanan yang dijadwalkan. Hasil kinerja pelayanan dalam perhitungan IPA terdapat 7 atribut yang termasuk dalam kuadran I yang terdiri dari pintu kereta, keteraturan jadwal kereta api, informasi gangguan perjalanan, fasilitas penumpang berkebutuhan khusus, tempat khusus kursi roda, fasilitas jaga jarak, serta pembersihan fasilitas dengan disinfektan oleh petugas OTC.Prioritas alternatif peningkatan kinerja operasional dan pelayanan adalah perawatan dan pemeriksaan sarana perkeretaapian secara berkala dengan nilai absolute importance 21,96 yaitu perawatan dan pemeriksaan sarana perkeretaapian secara berkala.

\section{UCAPAN TERIMA KASIH}

Ucapan terima kasih kami sampaikan kepada tim Laboratorium Environment Infrastructure and Information System (EIIS), Jurusan Perencanaan Wilayah dan Kota, Universitas Brawijaya beserta tim survei yang tidak bisa kami sebutkan satu persatu atas kerjasamanya yang luar biasa.

\section{REFERENSI}

Adika, W., \& Osly, P. J. (2018). Analisis Kinerja Operasional Kereta Api Jurusan JakartaPurwakarta (Studi Kasus Kereta Api Walahar Ekspres dan Cilamaya Ekspres). Journal Construction Engineering and Sustainable Development, 36-44. 
Annisa, R. N., \& Siti, N. (2018). Faktor-faktor yang Memengaruhi Permintaan Commuter Line Berdasarkan Fasilitas Park and Ride di Stasiun Sidoarjo. Jurnal Transportasi, A106.

Fadjar, H. M., Wiwandari, H., \& Jawoto, S. S. (2018). Pertumbuhan Pendudukn Perkotaan dan Perkembangan Pola Distribusinya Pada Kawasan Metropolitan Surakarta. Jurnal Wilayah dan Lingkungan, 215-233.

Fauzi, I., \& Palmaputri, T. C. (2015). Pengukuran Kepuasan Pelanggan Pengguna Jasa Kereta Api Komuter Madiun Jaya (Madiun-Yogyakarta). The 18th FSTPT International Symposium, Unila, Bandar Lampung.

Ibnu, F., \& Theresia, C. P. (2015). Pengukuran Kepuasan Pelanggan Pengguna Jasa Kereta Api Komuter Madiun Jaya (Madiun-Yogyakarta). The 18th FSTPT International Symposium, Unila, Bandar Lampung.

Jamaludin, Sadili, R., \& Alfisyahrin, A. (2019). Analisis Perjalanan Kereta Rel Listrik Pada Lintas Manggarai-Bogor. Jurnal Perkeretaapian Indonesia, 23-29.

Kota Surabaya Dalam Angka. (2019). Surabaya: Badan Pusat Statistik.

Masterplan Transportasi Kota Surabaya. (2017). Surabaya: Dinas Perhubungan.

Meyer, M.D. (1999). Demand management as an element of transportation policy: using carrots and sticks to influence travel behavior. Transport. Res. Pol. Pract. 33 (7-8),575599.

Modarres, A., 1993. Evaluating employer-based transportation demand management programs. Transport. Res. Pol. Pract., 27 (4), 291-297.

Nuryadi, A. (2017). Kajian Pemilihan Moda Bus dan Kereta Api Pada Pergerakan Penglaju Sidoarjo-Surabaya. Planning for Urban Region and Environment, 53-64.

Sarafina, R., Usman, B., \& Adamy, Y. (2019). Analisis Manajemen Transportasi Pada Angkutan Mini Bus. Jurnal Humaniora, 1-13.

Society for Human Resource Management. (2017). Employee benefits: remaining competitive in a challenging talent marketplace. https://www.shrm.org/hr-today/trendsand-forecasting/research-and-

surveys/Documents/2017\%20Employee\%20Benefits\%20Report.pdf. (Accessed 10 January 2020).

Statistik Komuter Gerbangkertosusila. (2017). Jakarta: Badan Pusat Statistik.

Sumantri, B. R., \& Herijanto, W. (2014). Analisis Kinerja Operasional Kereta Api Sriwedari Ekspress Jurusan Solo-Yogya. Jurnal Teknik POMITS, 1-6.

Tirachini, A., Hensher, D., Rose, J., (2013). Crowding in public transport systems: effects on users, operation and implications for the estimation of demand. Transport.Res.

Part A: Policy Pract., 53, 36-52.

Trisna, Irwansyah, D., Saptari, M. A., \& Maisyaroh. (2019). Analisis Kepuasan Konsumen Terhadap Kualitas Pelayanan Swalayan Dengan Metode Importance Performance Analysis dan Model Kano. Industrial Engineering Journal, 16-21. 
JournalHomepage: http://jurnal.ut.ac.id/reksabumi https://doi.org/10.33830/Reksabumi.v1i1.2209.2022

Yang, N., Lim, Y.L., (2018). Temporary Incentives Change Daily Routines: Evidence from a Field Experiment on Singapore's Subways. Manage. Sci., 64 (7), 3365-3379.

Zhang, Z., Fujii, H., Managi, S., (2014). How does commuting behavior change due to incentives? An empirical study of the Beijing subway system. Transport. Res. Part F: Traffic Psychol. Behav., 24, 17-26.

Zou, Q.R., Yao, X.M., Zhao, P., Wang, Z.J., Yang, T.Y., (2018). Measuring retiming responses of passengers to a prepeak discount fare by tracing smart card data: a practical experiment in the Beijing subway. J. Adv. Transport, 13, 18-33. 